\title{
Assessment of Genetic Parameters for Various Productive Traits in Early Maturing Sugarcane
}

\author{
Praveen Kumar $^{1 *}$, S.S. Pandey ${ }^{1}$, Balwant Kumar ${ }^{1}$, D.N. Kamat ${ }^{1}$ and Mahesh Kumar ${ }^{2}$ \\ ${ }^{1}$ Department of Plant Breeding and Genetics, ${ }^{2}$ Department of SMCA, Dr. Rajendra Prasad \\ Central Agricultural University, Pusa-848125 (Bihar), India \\ *Corresponding author
}

A B S T R A C T

\begin{tabular}{|l|}
\hline Key w o r d s \\
Sugarcane, Variability, \\
PCV, GCV, Heritability, \\
Genetic advance
\end{tabular}

Introduction

The cultivated varieties of sugarcane are interspecific hybrids involving at least three species, S. officinarum, $S$. barberi and $S$. spontaneum which themselves represent complex polyploidy. The chromosome number among varieties varies from $2 \mathrm{n}=100$ to 120 . It is for this reason the sugarcane varieties are botanically described as Saccharum spp. complex hybrid. The heterozygous and polyploid nature of this crop has resulted in generation of greater genetic variability. The extent of genetic variability present in any crop is of paramount importance for its improvement. The information on the nature and the magnitude of variability present in the genetic material is of prime importance for a breeder to initiate any effective selection program. Genotypic and phenotypic coefficients of variation along with heritability as well as genetic advance are very essential to improve productive trait of sugarcane because this would help in knowing whether or not the desired objective can be achieved from the material (Tyagi and Singh, 1998). So, present study was under taken to assess the extent of genetic variability, heritability, genetic advance of some important traits of early maturing sugarcane 
clones under subtropical India. Sugarcane is a perennial, tropical; monocotyledonous crop which is cultivated in tropical and subtropical region of the world primarily for its ability to store high concentration of sugar in the inter-node and propagate through stem cutting. The knowledge of nature and extent of genetic variation available in the germplasm or breeding material helps the breeder for planning sound breeding programmes. Therefore, present investigation was formulated to assess the genetic parameters for various productive traits.

\section{Materials and Methods}

The experimental materials were early maturing fifteen sugarcane clones namely CoSe 11451, CoSe 12451, CoLk 12207, CoLk 12208, CoP 11436, CoP 11438, CoP 12436, CoP 12437, CoP 13436, CoP 13437, CoP 16436, CoP 16437, CoP 16438, BO 153, CoP 11437 which were planted at Research farm of Dr. Rajendra Prasad Central Agricultural University, Pusa, Bihar, in a Randomized Block Design with three replications during 2015 - 16. Observations were record by selecting five random plants per genotype per replication for productive characters namely, germination $\%$ at 45 DAP, number of shoots at 120 DAP, plant height at 150, 240 and 300 days, cane diameter at harvest, number of millable canes, brix, pol, purity \%, extraction, fibre, CCS at $8 \& 10$ month stages, Pol in cane at harvest, single cane weight, sugar yield and cane yield at harvest.

\section{Brix $\%$ at 8 and 10 month stage}

It is a measure of total soluble solids present in the juice. It was taken directly by using a Brix hygrometer. $250 \mathrm{ml}$ juice was taken in measuring cylinder and hygrometer was dipped into the juice then reading was recorded from the juice level. These readings were corrected to the temperature at $20^{\circ}$ by using temperature correction chart as described by Spencer and Meade (1955).

\section{Pol \% at 8 and 10 month stage}

Pol refers to the sucrose per cent in juice. It was done according to the method described by Spencer and Meade (1955). It was estimated with the help of Polari scope. First $100 \mathrm{ml}$ juice was taken in conical flask and 4 gm Honey dry lead sub acetate was added and mixed well by shaking the flask.

After few minutes this solution was filtered twice through a dry Whatsman no. 1 filter paper and the abstract was collected into a clean and dry beaker. The abstract poured into the Polari meter tube. These tubes were placed in the Polari scope. Thereafter Pol values were recorded by polarising the clear juice in Polari scope this value called dial reading. Sucrose per cent in juice was obtained by referring the brix and dial reading to Schmitz's table. CCS $\%$ is determined by formula

$[\mathrm{S}-(\mathrm{B}-\mathrm{S}) \times 0.4] \times 0.73$

Where,

$\mathrm{S}=$ Sucrose percent in juice (pol \%).

$\mathrm{B}=$ Brix percent in juice.

The data were statistically analyzed. The analysis of variance (ANOVA) was worked out according to the procedure of Randomized Block Design for each character as per methodology advocated by Panse and Sukhatme (1967). The analysis of variance was used to derive variance components (Cochran and Cox, 1957).

\section{Estimation of genotypic and phenotypic coefficient of variation}

The formulae used to calculate PCV and GCV were given by Burton and De vane (1953). 


\section{Heritability (Broad sense)}

Heritability in broad sense was estimated by the formula given by Johnson et al., (1955). The heritability was categorized as low, moderate and high as given by Robinson et al., (1949).

\section{Genetic advance}

The estimates of genetic advance were obtained by the formula given by Lush (1949), Johnson et al., (1955) and Allard (1960). The range of genetic advance is classified as suggested by Johonson et al., (1955). Observed data for all the traits of 15 early maturing sugarcane clones were assessed for statistical analysis.

\section{Results and Discussion}

Variability is measure by estimation of genotypic and phenotypic variance, genotypic and phenotypic coefficient of variation (GCV and PCV), heritability, genetic advance and genetic advance as per cent of mean. These parameters help in selection for improvement of desired characters.

Environment plays an important role in the expression of phenotype. The phenotypic variability which is observable includes both genotypic (heritable) and environmental variation (non-heritable).

The analysis of variance (Table 1) showed highly significant differences for almost all the fifteen early maturing clones for twenty one traits.

This indicated that there is presence of sufficient variability in the material studied. The mean sum of square due to treatments was found highly significant for all the traits except brix at 10 month and pol in cane, these traits exhibit significant differences. Thus, it implied that there is reasonably sufficient variability in material used for their study, which provides ample scope for selecting superior and desire clone by the plant breeder for further improvement. Many earlier workers Doule and Balasundaram (2003), Singh et al., (2010) reported high variability for different traits in sugarcane. To decipher the amount of existing variability in the present clones, range, mean and standard error were calculated (Table 2) However, range is the crude method of estimation of variability, which indicates observed phenotypic variability only. It also showed the advisable range of co-efficient of variation for all the traits. From the perusal of the (Table 3), it is observed that phenotypic variances for all the characters under study are higher than genotypic variances. Similar result was reported by Verma and Singh (2002). This may be due to the non-genetic factor which played an important role in the manifestation of these characters. Comparatively the maximum phenotypic and genotypic variances were exhibited by the traits viz. plant height at 240 days, cane yield at harvest, plant height at 300 days, number of millable canes, plant height at (150) days, number of shoots at 120 DAP.

These findings were in accordance of Ravishankar et al., (2004) for cane yield/ plot and number of millable cane/ plot. The numerical value of phenotypic coefficient of variation is higher than their genotypic counterpart indicating that apparent variation is not only due to genotypes but also due to influence of environment. The narrow difference between PCV and GCV were recorded for most of the traits. Among morphological characters of clones moderate phenotypic and genotypic coefficient of variation were recorded for cane yield and single cane weight. The PCV and GCV of remaining traits were comparatively of lower magnitude. 
Table.1 Analysis of variance for twenty three traits of early maturing sugarcane clones

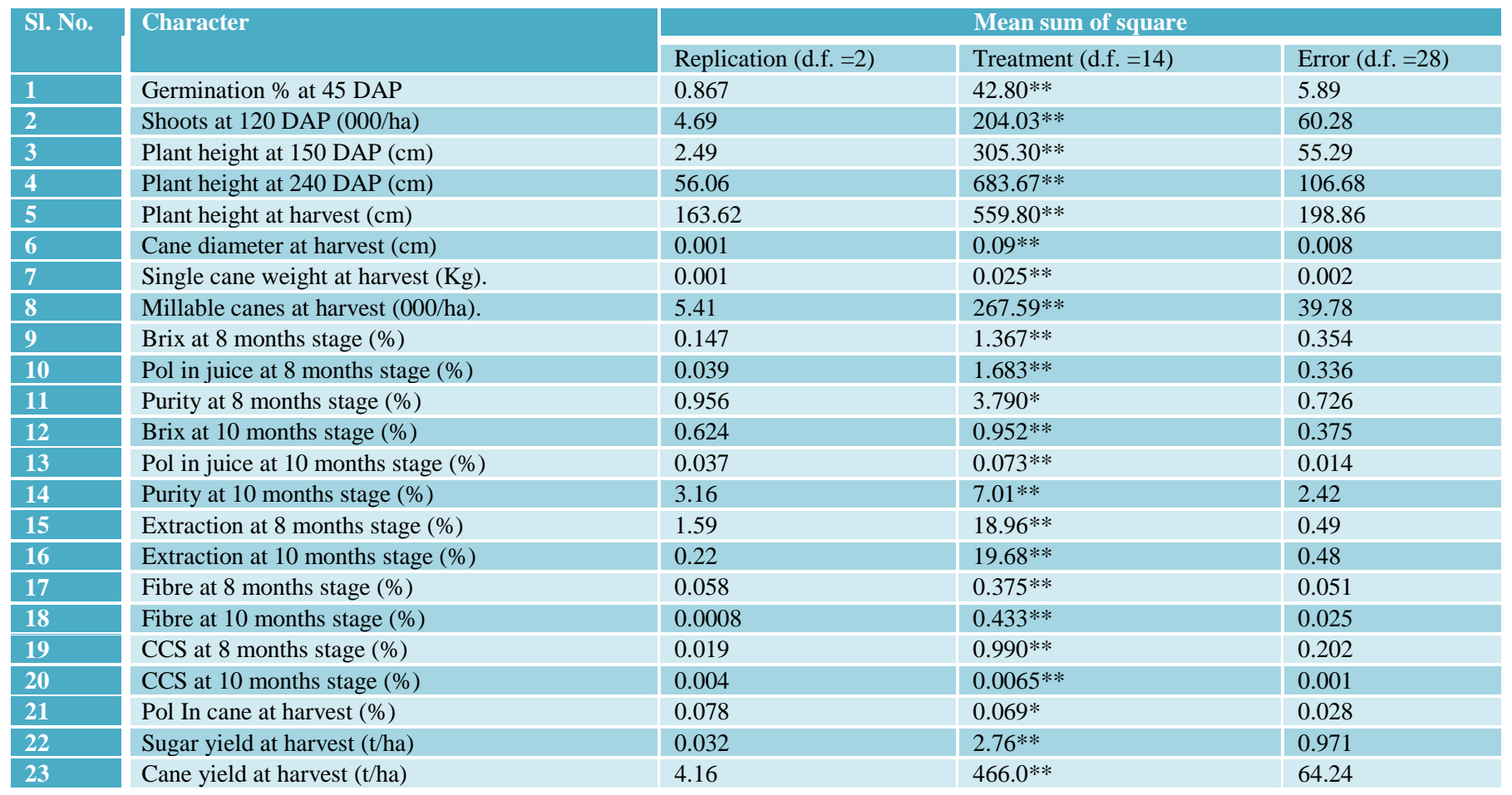

* Significant at 5\%,** significant at 1\% DAP - Days After Planting

Table.2 Mean, range and coefficient of variance for twenty three traits of early maturing sugarcane clones

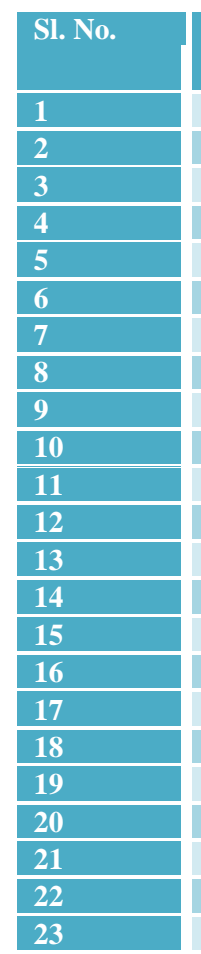

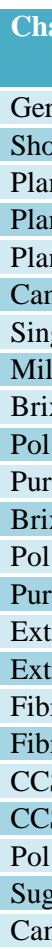

Character

Germination \% at 45 DAP

Shoots at 120 DAP (000/ha)

Plant height at 150 DAP $(\mathrm{cm})$

Plant height at 240 DAP $(\mathrm{cm})$

Plant height at harvest $(\mathrm{cm})$

Cane diameter at harvest $(\mathrm{cm})$

Single cane weight at harvest $(\mathrm{Kg})$.

Millable canes at harvest (000/ha).

Brix at 8 months stage (\%)

Pol in juice at 8 months stage (\%)

Purity at 8 months stage (\%)

Brix at 10 months stage (\%)

Pol in juice at 10 months stage (\%)

Purity at 10 months stage (\%)

Extraction at 8 months stage (\%)

Extraction at 10 months stage (\%)

Fibre at 8 months stage (\%)

Fibre at 10 months stage (\%)

CCS at 8 months stage (\%)

CCS at 10 months stage (\%)

Pol In cane at harvest (\%)

Sugar yield at harvest ( $\mathrm{t} / \mathrm{ha})$

Cane yield at harvest ( $\mathrm{t} / \mathrm{ha})$

\begin{tabular}{|l|l|l|l|}
\hline \multirow{2}{*}{ Mean \pm SEM } & \multicolumn{3}{|c|}{ Range } \\
\hline $39.00 \pm 1.40$ & 44.00 & 33.00 & 6.22 \\
\hline $100.78 \pm 4.48$ & 113.33 & 82.66 & 7.70 \\
\hline $99.08 \pm 4.29$ & 116.67 & 85.34 & 7.50 \\
\hline $180.93 \pm 5.96$ & 201.33 & 154.33 & 5.70 \\
\hline $272.37 \pm 8.14$ & 289.00 & 251.33 & 5.17 \\
\hline $2.55 \pm 0.05$ & 2.97 & 2.37 & 3.67 \\
\hline $0.85 \pm 0.026$ & 1.08 & 0.73 & 5.29 \\
\hline $98.67 \pm 3.64$ & 111.7 & 80.74 & 6.39 \\
\hline $18.67 \pm 0.343$ & 20.16 & 17.60 & 3.18 \\
\hline $16.49 \pm 0.33$ & 18.24 & 15.51 & 3.51 \\
\hline $88.28 \pm 0.49$ & 90.54 & 87.00 & 0.96 \\
\hline $21.85 \pm 0.35$ & 22.67 & 20.93 & 2.80 \\
\hline $18.57 \pm 0.07$ & 18.87 & 18.33 & 0.65 \\
\hline $85.05 \pm 0.89$ & 87.75 & 83.03 & 1.83 \\
\hline $53.81 \pm 0.407$ & 58.56 & 50.11 & 1.31 \\
\hline $56.31 \pm 0.40$ & 60.71 & 52.51 & 1.23 \\
\hline $14.93 \pm 0.13$ & 15.42 & 14.28 & 1.52 \\
\hline $13.11 \pm 0.92$ & 13.7 & 12.48 & 1.21 \\
\hline $11.40 \pm 0.25$ & 12.76 & 10.65 & 3.95 \\
\hline $12.60 \pm 0.02$ & 12.67 & 12.52 & 0.30 \\
\hline $14.28 \pm 0.97$ & 14.57 & 14.08 & 1.18 \\
\hline $10.27 \pm 0.57$ & 12.05 & 8.85 & 9.59 \\
\hline $83.98 \pm 4.62$ & 120.22 & 70.16 & 9.54 \\
\hline & & & \\
\hline & & & \multicolumn{1}{|c|}{ Max. } \\
\hline
\end{tabular}


Table.3 Genetic parameters for twenty three traits of early maturing sugarcane clones

\begin{tabular}{|c|c|c|c|c|c|c|c|}
\hline SI. No & Characters & $\sigma^{2} \mathbf{G}$ & $\sigma^{2} \mathbf{P}$ & GCV & PCV & $\mathbf{h}^{2}$ (bs) & GA M \\
\hline 1 & Germination $\%$ at 45 DAP & 12.30 & 18.20 & 8.99 & 10.93 & 67.63 & 15.23 \\
\hline 3 & Plant height at $150 \mathrm{DAP}(\mathrm{cm})$ & 83.33 & 138.63 & 9.21 & 11.88 & 60.11 & 14.71 \\
\hline 5 & Plant height at harvest $(\mathrm{cm})$ & 120.31 & 319.17 & 4.02 & 6.55 & 37.70 & 5.09 \\
\hline 6 & Cane diameter at harvest (cm) & 0.028 & 0.036 & 6.57 & 7.52 & 76.27 & 11.82 \\
\hline 7 & Single cane weight at harvest $(\mathrm{Kg})$. & 0.008 & 0.010 & 10.48 & 11.74 & 79.60 & 19.27 \\
\hline 10 & Pol in juice at 8 months stage (\%) & 0.44 & 0.78 & 4.06 & 5.37 & 57.12 & 6.32 \\
\hline 11 & Purity at 8 months stage (\%) & 1.02 & 1.74 & 1.14 & 1.49 & 58.45 & 1.80 \\
\hline 12 & Brix at 10 months stage $(\%)$ & 0.19 & 0.56 & 2.00 & 3.44 & 33.87 & 2.40 \\
\hline 13 & Pol in juice at 10 months stage (\%) & 0.02 & 0.03 & 0.75 & 0.99 & 56.85 & 1.16 \\
\hline 14 & Purity at 10 months stage $(\%)$ & 1.53 & 3.95 & 1.45 & 2.33 & 38.66 & 1.86 \\
\hline 15 & Extraction at 8 months stage (\%) & 6.15 & 6.65 & 4.61 & 4.79 & 92.5 & 9.13 \\
\hline 20 & CCS at 10 months stage (\%) & 0.001 & 0.003 & 0.32 & 0.44 & 54.61 & 0.49 \\
\hline 21 & Pol In cane at harvest (\%) & 0.01 & 0.04 & 0.81 & 1.43 & 13.62 & 0.95 \\
\hline 22 & Sugar yield at harvest (t/ha) & 0.59 & 1.56 & 7.51 & 12.19 & 38.03 & 9.55 \\
\hline 23 & Cane yield at harvest (t/ha) & 133.91 & 198.16 & 13.77 & 16.76 & 67.58 & 23.33 \\
\hline
\end{tabular}

The high heritability in broad sense was recorded in germination percentage, plant height at 150 days, cane diameter at harvest, single cane weight at harvest, milliable cane at harvest, extraction fibre and cane yield at harvest while cane yield at harvest exhibited high genetic advance as per cent of mean and single cane weight, germination $\%$, plant height at $150 \& 240$ days, cane diameter millable cane showed moderately genetic advance as per cent of mean.

In conclusion, High heritability coupled with high genetic advance as percent of means was observed for cane yield at harvest, suggesting the preponderance of additive genetic effect in the determination of these characters. It also indicated that selection for these characters will be effective for future improvement of clones. However, high heritability with moderate genetic advance as percent of means was observed Plant height at $150 \& 240$ days, cane diameter at harvest, single cane weight at harvest, milliable cane at harvest indicating the role of dominant genetic effects in determination of these characters and it require careful selection for the desired improvements in the characters.

\section{Acknowledgement}

Authors are thankful to Sugarcane Research Institute Pusa, Samastipur for providing early maturing sugarcane clones and all the members of Department of Plant Breeding and Genetics of DRPCAU Pusa for their support and providing necessary facilities.

\section{References}

Al-Sayed, H.M., Fateh, H.S.A; Fares, W.M. (2011). Investigation on variability, broad sensed heritability and genetic advance in sugarcane (Saccharum spp.). International Journal of Agri. Science. 2(9): 839-844.

Anshuman, S., P. K. Bhatnagar., Khan, A. Q. and Shrotria, P. K. (2002). Variability and heritability for cane yield, its components and quality characters in sugarcane (Saccharum spp complex). Indian Sug. J., 53(4): 717- 719.

Bairwa, A.K., Ram, R., Neetu., Jeena, A. S., Singh K. and Singh S. P. (2017). Estimation of the Extent of Variability for Different Morphological and Juice Quality Characters Among Early Generation 
Sugarcane Clones. Int.J.Curr. Microbiol.App.Sci. 6(2): 1272-1278.

Bhatnagar, P. K., A. Q. Khan, A. Singh and K. A. Khan (2003). Studies on genetic variability, heritability and genetic advance in plant and ratoon crops of sugarcane. Indian Sugar, 53(3): 183-185.

Burton, G. W. and De Vane (1953). Estimating heritability in tall Fescue from replicated clonal material. Agron. J. 45: 475 - 481

Chandrakant; Ravikant and Singh, P. K. (2007). Screening criteria for selection of superior clones in early clonal generation of Saccharum complex hybrids. Crop Improvement. 34(1): 63-71.

Doule, R. B. and Balasundaram, N. (2002). Genetic variability in sugar yield and its components for selection of sugarcane. Journal of Maharashtra Agricultural Universities. 27(3): 326-327.

Falconer, D. S. (1989). Introduction to quantitative genetics. $3^{\text {rd }}$ edition Longman. New York.

Fisher, R. A. and Yates, F. (1938). Statistical tables for Biological, Agricultural and Medical Research.

Islam, M-S; Miah, M-A-S; Begum, M-K; Alam, M-R; Arefin, M-S. (2011).Growth, yield and juice quality of some selected sugarcane clones under, water-logging stress condition. World-Journal-ofAgricultural-Sciences. 7(4): 504-509.

Johnson, H. W., Robinson, H. F. and Comstock, R. E. (1955a). Estimates of genetic and environmental variability in soybeans. Agron. J. 47: $314-318$.

Kamat, D. N. and Singh, J. R. P. (2001). Variability in sugarcane under rainfed condition. Sugar Tech. 3 (1): (1\&2): 65-67.

Khalid, M., Rahman, H., Rabban, A., Farahatullah and Khan (2014). Qualitative and quantitative assessment of newly selected sugarcane Sarhad J. Agric. Vol. 30, No. 2.
Kumar, R. and Singh, J. R. P. (1999). Variability in sugarcane under water-logged condition. Journal of Applied Biology. 9(2): 140-142.

Nair, N. V. and Somarajan, K. G. and Balasundaram, N. (1980). Genetic variability, heritability and genetic advance in S. officinarum L. Inter. Sugar. J. 82(981): 275-276.

Panse, V. G. and Sukhatme, P. V. (1967). Statistical methods of agricultural workers $2^{\text {nd }}$ edn. pp. 381, ICAR, Publication, New Delhi.

Puneet Jain., Rishi Pal., Saini, M. L. and Lajpat Rai. (2001). Variability, heritability and genetic advance for yield attributes in sugarcane. Indian Sugar. 51(5): 321-324.

Rahman, M. M. and Bhuiyan, M. S. R. (2009). Variability, heritability and genetic advanced for cane yield and its components in some indigenous and exotic promising clones of sugarcane (Saccharum officinarum L). Indian Sugar. 59(2): 35-42.

Sabitha, N., Rao, K. P., Rao, C. P. and Rao, M. S. (2007). Genetic variation, heritability and genetic advance for yield components in sugarcane. Sugar Tech. 9(4): 290-292

Singh, M. K., Pandey, S. S., Kumar, R. and Singh, A. K. (2010). Estimation of genetic variability, heritability and genetic advance in mid-late maturing clones of sugarcane. Environment and Ecology. 28(4): 23012305.

Spencer, G.L. and Meade, G.P. 1955. Cane Sugar Hand Book. J. Wiley and Sons, N.Y.

Thippeswamy, S., Kajjidoni, S. T., Salimath, P. M., Goud, J. V. and Chetti, M. B. (2001). Variability, heritability and genetic advance for cane yield and its components in sugarcane. Karnataka J. Agri. Sci. 14(1): 30-34.

Tyagi, V.K., Sharma, Satish and Bhardwaj, S. B. (2011). A study on the nature and magnitude of variations in different traits in sugarcane. Electronic Journal of Plant Breeding. 2(3): 334-341.

\section{How to cite this article:}

Praveen Kumar, S.S. Pandey, Balwant Kumar, D.N. Kamat and Mahesh Kumar. 2018. Assessment of Genetic Parameters for Various Productive Traits in Early Maturing Sugarcane. Int.J.Curr.Microbiol.App.Sci. 7(05): 1387-1392. doi: https://doi.org/10.20546/ijcmas.2018.705.164 